\title{
An Investigation into the Barriers for University Students to the Use of Recreation Areas
}

\author{
Osman Tolga Togo ${ }^{1, *} \&$ Arda Öztürk ${ }^{2}$ \\ ${ }^{1}$ School of Physical Education and Sports, Department of Physical Education and Sport, Harran University, Sanliurfa, \\ Turkey \\ ${ }^{2}$ Faculty of Sport Sciences, Department of Recreation, Pamukkale University, Denizli, Turkey \\ *Correspondence: School of Physical Education and Sports, Department of Physical Education and Sport, Harran \\ University, Sanlıurfa 6300, Turkey. E-mail: tolgatogo@gmail.com
}

Received: September 26, 2019

Accepted: November 27, 2019

Online Published: December 18, 2019

doi:10.5430/wje.v9n6p28

URL: https://doi.org/10.5430/wje.v9n6p28

\begin{abstract}
In this research, it is aimed to determine the participation barriers of the students who are studying in sports departments of the university and living in different geographical areas related to the use of recreation area by the municipalities. The study group, the universities in four regions in Turkey 135 girls and 197 boys studying sports science constitute a total of 332 students. As a data collection tool; Gümüs, H. \& Alay Özgül, S. The scale of participation barriers to the use of recreation area consisting of 17 questions and five sub-dimensions developed in 2017 was used. The findings show that the data do not have a normal distribution. In the evaluation of the data, Mann Whitney-U test was used for paired comparisons and Kruskall Wallis Analysis test was used for three and more comparisons, and significant differences were found in the sub-dimensions of department variable, gender, place of residence and use of private vehicles $(\mathrm{P}<0.05)$.
\end{abstract}

Keywords: recreation, sports sciences, participation barriers

\section{Introduction}

People's lessening active lifestyles and various health problems that appear together with technological advancements, increase in education level and the process of urbanization reveal the importance of recreation areas.

Recreation is not an activity that is performed unconsciously as a kind of rewarding, but an activity that offers the participant physical, mental and creative powers and that we participate in as a leisure with an inner desire without external force (Balc1, 2003).

Students in higher education institutions have an important place in Turkey's population. Besides, young people are the potential power of the country's future with their dynamic traits. For this reason, these students' participation in recreation activities and the way they spend their free time are common concerns of higher education institutions (Mutlu, 2008).

University students spend their free time and participate in recreational activities in a semi-organized manner within the scope of the opportunities provided by their schools during their university education. In this sense, universities can also play a guiding role for students to make use of their time efficiently outside their formal education (Özşaker, 2012). Young people's efficient use of their leisure time is essential in terms of preventing socio-cultural, economical, health and educational problems. Therefore, it is necessary to develop social and cultural activities in universities in order for students to pass their leisure time in an educational way (Korkmaz, 2000).

In establishing the economic value of recreation, first of all, it is of critical importance to determine whether it is possible for a person to create free time to participate in recreational activities; and if time can be allocated for such activities, then its duration should be determined. In today's societies, people's free time is mostly determined according to economic, social and other factors rather than people's own wills (compulsory working hours) (Mutlu, 2008). According to recent studies, it has also been observed that people participate in passive activities in their spare time (Temir and Gürbüz; 2012). 


\section{Methodology}

\subsection{Aim of the Study}

This study aims to investigate the barriers for university students studying in sports sciences departments and living in different geographical areas to use recreation areas provided by municipalities.

\subsection{Participants of the Study}

The population of the study consisted of students studying in sports sciences departments in Turkey while the sample included a total of 332 consisting of 135 girls and 197 boys studying sports sciences at universities in four regions of Turkey (Marmara-Gelisim-Harran-Muğla-Rize).

\subsection{Data Collection Tools}

In this study, the scale for barriers to participation in recreation developed by Gümüş, H. \& Alay Özgül, S. in 2017, consisting of 17 questions and five subdimensions, was used. The scale is a 5-point scale (1: Strongly Disagree, 2: Disagree, 3: Undecided, 4: Agree, 5: Completely Agree). The studies that were benefitted from during the development of the scale were those of Wilcox, Castro, King, Housemann and Brownson (2000); Arnold and Shinew (1998); Stanis, Schneider, Chavez and Shinew (2009) in the subdimension of "Security Barrier" (4 items); Gürbüz, Öncü and Emir (2012); Tütüncü et al. (2011) in the subdimension of "Time Barrier" (2 items); Gürbüz, Öncü and Emir (2012) in the subdimension of "Friend Barrier" (3 items); Gürbüz, Öncü and Emir (2012); Wilcox, Castro, King, Housemann and Brownson (2000) in the subdimension of "Individual Barrier" (4 items). Other than these, 4 items were added by the researcher.

\subsection{Data Analysis}

The analysis of the research was carried out in SPSS package program. Mann Whitney U test was used for paired comparisons and Kruskall Wallis Analysis test was used to make comparisons of three and more groups.

\section{Findings}

Table 1. Kruskall Wallis Test Results Regarding the Subdimensions of Recreation Area Participation Barrier Scale According to Age Variable

\begin{tabular}{|c|c|c|c|c|c|c|}
\hline Subdimensions & Age & $\mathrm{N}$ & Mean Rank & sd & $\mathrm{X}^{2}$ & $\mathrm{P}$ \\
\hline \multirow{3}{*}{ Security } & $18-21$ & 151 & 164,62 & \multirow{3}{*}{2} & \multirow{3}{*}{,323 } & \multirow{3}{*}{,851 } \\
\hline & $22-25$ & 138 & 169,91 & & & \\
\hline & $26+$ & 43 & 162,14 & & & \\
\hline \multirow{3}{*}{ Time } & $18-21$ & 151 & 162,73 & \multirow{3}{*}{2} & \multirow{3}{*}{2,40} & \multirow{3}{*}{,300 } \\
\hline & $22-25$ & 138 & 175,19 & & & \\
\hline & $26+$ & 43 & 151,87 & & & \\
\hline \multirow{3}{*}{ Friend } & $18-21$ & 151 & 178,01 & \multirow{3}{*}{2} & \multirow{3}{*}{4,28} & \multirow{3}{*}{, 117} \\
\hline & $22-25$ & 138 & 158,85 & & & \\
\hline & $26+$ & 43 & 150,64 & & & \\
\hline \multirow{4}{*}{ Sports Area } & $18-21$ & 151 & 167,35 & \multirow{3}{*}{2} & \multirow{3}{*}{2,77} & \multirow{3}{*}{, 250} \\
\hline & $22-25$ & 138 & 172,34 & & & \\
\hline & $26+$ & 43 & 144,78 & & & \\
\hline & $18-21$ & 151 & 178,42 & \multirow{3}{*}{2} & \multirow{3}{*}{5,79} & \multirow{3}{*}{, 055} \\
\hline \multirow{2}{*}{ Individual } & $22-25$ & 138 & 161,36 & & & \\
\hline & $26+$ & 43 & 141,12 & & & \\
\hline
\end{tabular}

As is seen in Table 1, Kruskall Wallis test was used to determine whether Recreation Area Participation Barrier scale subdimension scores differed according to age variable, and as a result of the analysis, no statistically significant difference was found between recreation area participation barrier and age variable. 
Table 2. Kruskall Wallis Test Results Regarding the Subdimensions of Recreation Area Participation Barrier Scale According to Department Variable

\begin{tabular}{|c|c|c|c|c|c|c|}
\hline Subdimensions & Department & $\mathrm{N}$ & Mean Rank & sd & $\mathrm{X}^{2}$ & $\mathrm{P}$ \\
\hline \multirow{7}{*}{ Security } & Teaching & 119 & 153,96 & \multirow{5}{*}{3} & \multirow{5}{*}{3,82} & \multirow{5}{*}{,281 } \\
\hline & Coaching & 112 & 178,30 & & & \\
\hline & Sport & 73 & 169.45 & & & \\
\hline & Management & 15 & 109,43 & & & \\
\hline & Recreation & 28 & 164,93 & & & \\
\hline & Teaching & 119 & 140,90 & \multirow{4}{*}{3} & \multirow{4}{*}{17,17} & \multirow{4}{*}{,001* } \\
\hline & Coaching & 112 & 190,27 & & & \\
\hline \multirow[t]{3}{*}{ Time } & Sport & 73 & 177,23 & & & \\
\hline & Recreation & 28 & 152,25 & & & \\
\hline & Teaching & 119 & 162,47 & \multirow{4}{*}{3} & \multirow{4}{*}{, 54} & \multirow{4}{*}{,908 } \\
\hline \multirow{3}{*}{ Friend } & Coaching & 112 & 170,24 & & & \\
\hline & $\begin{array}{c}\text { Sport } \\
\text { Management }\end{array}$ & 73 & 164,75 & & & \\
\hline & Recreation & 28 & 173,20 & & & \\
\hline \multirow{5}{*}{ Sports Area } & Teaching & 119 & 146,01 & \multirow{5}{*}{3} & \multirow{4}{*}{8,96} & \multirow{4}{*}{, $030 *$} \\
\hline & Coaching & 112 & 181,59 & & & \\
\hline & $\begin{array}{c}\text { Sport } \\
\text { Management }\end{array}$ & 73 & 174,75 & & & \\
\hline & Recreation & 28 & 171,70 & & & \\
\hline & Teaching & 119 & 159,36 & & \multirow{4}{*}{4,20} & \multirow{4}{*}{,240 } \\
\hline \multirow{3}{*}{ Individual } & Coaching & 112 & 181,55 & \multirow{3}{*}{3} & & \\
\hline & $\begin{array}{c}\text { Sport } \\
\text { Management }\end{array}$ & 73 & 158,07 & & & \\
\hline & Recreation & 28 & 158,63 & & & \\
\hline
\end{tabular}

As Table 2 indicates, Kruskall Wallis test was performed to determine whether Recreation Area Participation Barrier subdimension scores of the individuals participating in the study showed a significant difference according to department variable, and as a result of the analysis, a statistically significant difference was found between recreation area participation barrier and department variable in time and sports area subdimensions.

Table 3. Mann Whitney U Test Results Regarding the Subdimensions of Recreation Area Participation Barrier Scale According to Gender Variable

\begin{tabular}{|c|c|c|c|c|c|c|}
\hline Subdimensions & Gender & $\mathrm{N}$ & Mean Rank & Sum of Ranks & $\mathrm{U}$ & $\mathrm{P}$ \\
\hline \multirow{2}{*}{ Security } & Male & 197 & 146,31 & 28823,50 & \multirow{2}{*}{9320,50} & \multirow{2}{*}{,000" } \\
\hline & Female & 135 & 195,96 & 26454,50 & & \\
\hline \multirow{2}{*}{ Time } & Male & 197 & 153,18 & 30176,50 & \multirow{2}{*}{10673,50} & \multirow{2}{*}{, 002} \\
\hline & Female & 135 & 185,94 & 25101,50 & & \\
\hline \multirow{2}{*}{ Friend } & Male & 197 & 169,37 & 33366,00 & \multirow[t]{2}{*}{12732,00} & \multirow{2}{*}{, 507} \\
\hline & Female & 135 & 162,31 & 21912,00 & & \\
\hline \multirow{2}{*}{ Sports Area } & Male & 197 & 158,82 & 31288,50 & \multirow{2}{*}{11785,50} & \multirow{2}{*}{, 076} \\
\hline & Female & 135 & 177,70 & 23989,50 & & \\
\hline \multirow[t]{2}{*}{ Individual Barriers } & Male & 197 & 163,63 & 32235,50 & \multirow{2}{*}{12732,50} & \multirow{2}{*}{, 508} \\
\hline & Female & 135 & 170,69 & 23042,50 & & \\
\hline
\end{tabular}


According to Table 3, Mann Whitney-U test was used to determine whether Recreation Area Participation Barrier scale subdimension scores showed a significant difference according to gender variable, and as a result of the analysis, a statistically significant difference was found between recreation area participation barrier scores and gender variable in security barrier and time barrier subdimensions and this difference was found to be in favours of women.

Table 4. Mann Whitney U Test Results Regarding the Subdimensions of Recreation Area Participation Barrier Scale According to University Type Variable

\begin{tabular}{|c|c|c|c|c|c|c|}
\hline Subdimensions & University & $\mathrm{N}$ & Mean Rank & Sum of Ranks & $\mathrm{U}$ & $P$ \\
\hline \multirow{2}{*}{ Security } & State & 309 & 165,72 & 51207,00 & \multirow{2}{*}{3312,00} & \multirow{2}{*}{, 585} \\
\hline & Foundation & 23 & 177,00 & 4071,00 & & \\
\hline \multirow{2}{*}{ Time } & State & 309 & 165,41 & 51111,00 & \multirow{2}{*}{3216,00} & \multirow{2}{*}{,443 } \\
\hline & Foundation & 23 & 181,17 & 4167,00 & & \\
\hline \multirow{2}{*}{ Friend } & State & 309 & 165,79 & 51229,00 & \multirow[t]{2}{*}{3334,00} & \multirow{2}{*}{,618 } \\
\hline & Foundation & 23 & 176,04 & 4049,00 & & \\
\hline \multirow[t]{2}{*}{ Sports Area } & State & 309 & 166,70 & 51510,50 & \multirow{2}{*}{3491,50} & \multirow{2}{*}{, 888} \\
\hline & Foundation & 23 & 163,80 & 3767,50 & & \\
\hline \multirow[t]{2}{*}{ Individual } & State & 309 & 167,51 & 51760,00 & \multirow{2}{*}{3242,00} & \multirow{2}{*}{, 481} \\
\hline & Foundation & 23 & 152,96 & 3518,00 & & \\
\hline
\end{tabular}

As Table 4 demonstrates, Mann Whitney-U test was used to determine whether Recreation Area Participation Barriers subdimension scores showed a significant difference according to university type variable, and no statistically significant difference was found between the recreation area participation barrier and the university variable.

Table 5. Mann Whitney U Test Results Regarding the Subdimensions of Recreation Area Participation Barrier Scale According to Marital Status Variable

\begin{tabular}{|c|c|c|c|c|c|c|}
\hline Subdimensions & Marital Status & $\mathrm{N}$ & Mean Rank & Sum of Ranks & U & $\mathrm{P}$ \\
\hline \multirow{2}{*}{ Security } & Married & 14 & 167,14 & 2340,00 & \multirow{2}{*}{2217,00} & \multirow{2}{*}{,979 } \\
\hline & Single & 318 & 166,47 & 52938,00 & & \\
\hline \multirow{2}{*}{ Time } & Married & 14 & 163,25 & 2285,50 & \multirow{2}{*}{2180,50} & \multirow{2}{*}{,896 } \\
\hline & Single & 318 & 166,64 & 52992,50 & & \\
\hline \multirow{2}{*}{ Friend } & Married & 14 & 187,29 & 2622,00 & \multirow[t]{2}{*}{1935,00} & \multirow{2}{*}{,404 } \\
\hline & Single & 318 & 165,58 & 52656,00 & & \\
\hline \multirow[t]{2}{*}{ Sports Area } & Married & 14 & 148,07 & 2073,00 & \multirow{2}{*}{1968,00} & \multirow{2}{*}{,459 } \\
\hline & Single & 318 & 167,31 & 53205,00 & & \\
\hline \multirow[t]{2}{*}{ Individual } & Married & 14 & 178,61 & 2500,50 & \multirow{2}{*}{2056,50} & \multirow{2}{*}{,628 } \\
\hline & Single & 318 & 165,97 & 52777,50 & & \\
\hline
\end{tabular}

Table 5 reveals that Mann Whitney-U test was performed to determine whether Recreation Area Participation Barrier subdimension scores of the individuals participating in the study showed a significant difference according to marital status variable, and no statistically significant difference was found between recreation area participation barrier and marital status variable. 
Table 6. Mann Whitney U Test Results Regarding the Subdimensions of Recreation Area Participation Barrier Scale According to the City Variable

\begin{tabular}{|c|c|c|c|c|c|c|}
\hline Subdimensions & City & $\mathrm{N}$ & Mean Rank & Sum of Ranks & $\mathrm{U}$ & $\mathrm{P}$ \\
\hline \multirow{2}{*}{ Security } & Istanbul & 66 & 180,47 & 11911,00 & \multirow{2}{*}{7856,00} & \multirow{2}{*}{, 185} \\
\hline & Other & 266 & 163,03 & 43367,00 & & \\
\hline \multirow{2}{*}{ Time } & Istanbul & 66 & 183,96 & 12141,50 & \multirow{2}{*}{7625,50} & \multirow{2}{*}{,096 } \\
\hline & Other & 266 & 162,17 & 43136,50 & & \\
\hline \multirow{2}{*}{ Friend } & Istanbul & 66 & 140,57 & 9277,50 & \multirow{2}{*}{7066,50} & \multirow{2}{*}{,013* } \\
\hline & Other & 266 & 172,93 & 46000,50 & & \\
\hline \multirow{2}{*}{ Sports Area } & Istanbul & 66 & 173,50 & 11451,00 & \multirow{2}{*}{8316,00} & \multirow{2}{*}{, 505} \\
\hline & Other & 266 & 164,76 & 43827,00 & & \\
\hline \multirow{2}{*}{ Individual } & Istanbul & 66 & 138,15 & 9118,00 & \multirow{2}{*}{6907,00} & \multirow{2}{*}{, $007 *$} \\
\hline & Other & 266 & 173,53 & 46160,00 & & \\
\hline
\end{tabular}

As Table 6 indicates, Mann Whitney-U test was performed to determine whether Recreation Area Participation Barrier scale subdimension scores showed a significant difference according to city variable, and statistically significant differences were found between recreation area participation barrier and city, and this difference was found to be in favour of other cities.

Table 7. Mann Whitney U Test Results Regarding the Subdimensions of Recreation Area Participation Barrier Scale According to Private Car Variable

\begin{tabular}{|c|c|c|c|c|c|c|}
\hline Subdimensions & Private Car & $\mathrm{N}$ & Mean Rank & Sum of Ranks & $\mathrm{U}$ & $\mathrm{P}$ \\
\hline \multirow{2}{*}{ Security } & Yes & 58 & 149,31 & 8660,00 & \multirow{2}{*}{6949,00} & \multirow{2}{*}{,132 } \\
\hline & No & 274 & 170,14 & 46618,00 & & \\
\hline \multirow{2}{*}{ Time } & Yes & 58 & 167,37 & 9707,50 & \multirow{2}{*}{7895,50} & \multirow{2}{*}{,939 } \\
\hline & No & 274 & 166,32 & 45570,50 & & \\
\hline \multirow{2}{*}{ Friend } & Yes & 58 & 149,31 & 8660,00 & \multirow{2}{*}{6949,00} & \multirow{2}{*}{,130 } \\
\hline & No & 274 & 170,14 & 46618,00 & & \\
\hline \multirow[t]{2}{*}{ Sports Area } & Yes & 58 & 134,44 & 7797,50 & \multirow{2}{*}{6086,50} & \multirow{2}{*}{,005* } \\
\hline & No & 274 & 173,29 & 47480,50 & & \\
\hline \multirow[t]{2}{*}{ Individual } & Yes & 58 & 139,66 & 8100,00 & \multirow{2}{*}{6389,00} & \multirow{2}{*}{,018* } \\
\hline & No & 274 & 172,18 & 47178,00 & & \\
\hline
\end{tabular}

As is seen in Table 7, Mann Whitney-U test was conducted to determine whether Recreation Area Participation Barrier scale subdimension scores of the individuals participating in the study showed a significant difference according to having a private car, and as a result of the analysis, statistically significant difference was found between recreation area participation barrier and private car variable in sports area and individual barriers subdimensions. According to the means, this difference was found to be in favors of "no".

\section{Discussion}

The aim of this study was to determine university students' recreation area participation barriers. In this study, no significant difference was found in recreation area use according to age, university and marital status variables $(\mathrm{P}>$ 0.05). However, in the study conducted by Demirel \& Harmandar (2009), when students' attitudes towards the sub-factors that prevented participation in recreational activities were examined, a significant relationship was observed in facility/service and transportation, social environment and lack of information and individual psychology subdimensions according to university type variable. In the study by Gümüş (2016) as well, a significant difference was found according to age, marital status and education level variables. While this difference was in sports area 
barrier subdimension according to age variable; it is in security and friend barrier subdimensions according to education level variable and in security and time barrier sub-dimensions according to marital status variable.

In this study, there is a significant difference in recreation area use according to department, gender, city and private car variables. This difference was found to be significant in time and sports area barrier subdimensions according to department variable; and in security and time barrier subdimensions according to gender variable in favor of women. When we examine this situation in terms of women, the underlying reasons can be because of the fact that the burden of women in all areas of life is higher than men and that women do not feel safe. In addition, when we look at the relevant literature (Gürbüz and Henderson, 2014; Gürbüz and Henderson, 2013), it is stated that women face more obstacles in terms of participation in recreation than men. However, according to the results of the study conducted by Kurtepe (2018), it was seen that in terms of gender variable, there was a difference in favour of female students in individual psychology, lack of information, lack of time and lack of interest subdimensions; and in lack of friends subdimension in favour of male students.

It is also seen that the students living outside Istanbul encounter more obstacles in friends barrier and individual area barrier subdimensions according to city variable. Finally, according to private car variable, it is revealed that there is a significant difference in sports area and individual barriers, and not having a private car affects the participation of students in sports areas or individual recreational activities.

Toprak et al. (2014) stated that the existing recreation areas (city and neighbourhood parks, sports areas, playgrounds, etc.) are insufficient in terms of quality and quantity, and that the frequency of using these unsatisfactory areas by the students is low. In the study by Çebi et al. (2018), when the results of sport science and other departments students' free time participation barriers were examined, it was revealed that there was no significant difference and that the students were affected by individual and environmental conditions in terms of participation barrier.

\section{Conclusion}

The results of the study present some important implications for researchers, institutions and all the other stakeholders are as follows: While Recreation Area Participation Barrier scale subdimension scores differed according to the age, type of university and marital status, no meaningful difference was found between recreation area participation barriers. On the other hand, Recreation Area Participation Barriers subdimension scores of the participants showed a significant difference according to their departments, and as a result of the analysis, a statistically significant difference was found between recreation area participation barrier and department variable in time and sports area subdimensions. According to this scale, subdimension scores showed a significant difference according to gender, city and private car and as a result of the analysis, a statistically significant difference was found between recreation area participation barrier scores and gender variable in security barrier and time barrier subdimensions, and this difference was found to be in favour of women. In addition, a statistically significant difference was found between participation barrier and gender variable in security and time subdimension and according to city variable, statistically significant differences were found between recreation area participation barrier and city, and this difference was found to be in friends and individual subdimensions. Finally, according to the private car variable subdimension, sport area and individual variables were found statistically meaningful.

To conclude, in many studies, it is described that recreation is defined as activities that are participated in voluntarily in free time (Kilbas, 2010). In brief, participation of individuals in recreational activities in their free time will provide essential contributions both to their physical and mental health and also to our social integrity.

\section{References}

Arnold, M. L., \& Shinew, K. J. (1998). The role of gender, race, and in come on park use constraints. Journal of Park and Recreation Administration, 16(4), 39-56.

Badia, M., Orgaz, B. M., Verdugo, M. A., Ullan M. A., \& Martinez, M. M. (2011). Personal factors and perceived barriers to participation in leisure activities for young and adults with developmental disabilites. Research in Developmental Disabilities, 32, 2055-2063. https://doi.org/10.1016/j.ridd.2011.08.007

Balcı, V. (2003). Ankara'daki Üniversite Öğrencilerinin Boş Zaman Etkinliklerine Katılımlarının Araştırılması. Milli Eğitim Dergisi, 158.

Çebi ve ark. (2018). Spor Bilimleri ve Diğer Fakülte Öğrencilerinin Boş Zaman Faaliyetlerine Katılım Engellerinin İncelenmesi. Gaziantep Üniversitesi Spor Bilimleri Dergisi, 3(1), 23-30. https://doi.org/10.31680/gaunjss.408928 
Demirel, M., \& Harmandar, D. (2009). Üniversite öğrencilerinin rekreasyonel etkinliklere katılımlarında engel oluşturabilecek faktörlerin belirlenmesi. Uluslararası İnsan Bilimleri Dergisi.

Ekinci eve ark. (2014). Üniversite Öğrencilerinin Sportif ve Sportif Olmayan Rekreatif Etkinliklere Katılmalarına Engel Olabilecek Unsurların İncelenmesi, Sportif Bakış. Spor ve Eğitim Bilimleri Dergisi, 1(1), 1-13.

Gümüş, H. (2016). Rekreasyonel Alanların Kullanım Etkenlerinin İncelenmesi. Gazi Üniversitesi Sağllk Bilimleri Enstitüsü, Beden Eğitimi ve Spor Anabilim dalı Doktora Tezi, Ankara.

Gürbüz, B., \& Henderson, K. A. (2013). Exploring the Meanings of Leisure among Turkish University Students. Croatian Journal of Education, 15(4), 927-957. https://doi.org/10.17718/tojde.54964

Gürbüz, B., \& Henderson, K. A. (2014). Leisure activity preferences and constraints: Perspectives from Turkey. Word Leisure Journal, 56(4), 300-316. https://doi.org/10.1080/16078055.2014.958195

Gürbüz, B., Öncü, E., \& Emir, E. (2012). Leisure contraints questionnaire: testing the construct validity. 12th International Sports Sciences Congress, 339-343, 12-14 December, Denizli, Turkey.

Kılbaş, Ş. (2010). Rekreasyon, Gazi Kitapevi, 4. Bask1, Ankara.

Kırtepe, A. (2018). Üniversite Öğrencilerinin Rekreasyonel Aktivitelere Katılımına Engel Olan Unsurların Farklı Değişkenler Açısından İncelenmesi. TurkishStudiesSocialSciences, 13(18), 901-910. https://doi.org/10.7827/TurkishStudies.14142

Korkmaz, A. (2000). Yüksek Öğretim Gençliğinin Problemleri.Milli Ĕ̈itim, 145, 41-45.

Mutlu, İ. (2008). Egzersiz Yapan Kişilerin Boş Zamanlarına Yönelik Tutumları Üzerine Bir Araştırma: Kayseri İli Örneği, Yayınlanmamış Yüksek Lisans Tezi, Niğde Üniversitesi Sosyal Bilimler Enstitüsü.

Özşaker, M. (2012). Gençlerin Serbest Zaman Aktivitelerine Katılamama Nedenleri Üzerine Bir İnceleme. Selçuk Üniversitesi Beden Ĕ̈itimi Ve Spor Bilim Dergisi, 14(1), 126-131.

Stanis, S. A. W., Schneider, I. E., Chavez, D. J., \& Shinew, K. J. (2009). Visitor constraints to physical activity in park and recreationareas: Differences by race and ethnicity. Journal of Park and Recreation Administration, 27(3), 78-95.

Temir, Ö., \& Gürbüz, B. (2012). Rekreasyonel Aktivitelere Katılımın Önündeki Engellerin İncelenmesi, I. Rekreasyon Araştırmaları Kongresi Kemer, Antalya.

Toprak ve ark (2014). Öğrencilerin Üniversiteden Rekreasyon Aktiviteleri Konusunda Beklentileri. VII. Lisansüstü Turizm Öğrencileri Araştırma Kongresi: 592-604, 04-05 Nisan 2014, Kuşadası, Aydın.

Tütüncü, Ö ve ark. (2011). Üniversite öğrencilerinin rekreasyon faaliyetlerine katılımını etkileyen unsurların analizi. Spor Bilimleri Dergisi, 22, 69-83.

Wilcox, S., Castro, C., King, A. C., Housemann, R., \& Brownson, R. C. (2000). Determinants of leisure time physical activity in rural compared with urban older and ethnically diverse women in the United States. Journal of Epidemiology Community Health, 54, 667-673. https://doi.org/10.1136/jech.54.9.667 